\title{
Effect of Different Slaughter Weights on Slaughter and Carcass Traits of Male Karayaka Lambs Reared under Intensive Production System
}

\author{
Yüksel Aksoy $^{1 *}$, Zafer Ulutaş ${ }^{2}$ \\ ${ }^{1}$ Department of Animal Science, Faculty of Agriculture, University of Gaziosmanpaşa, 60250 Tokat, Turkey \\ ${ }^{2}$ Department of Animal Production and Technologies, Faculty of Agricultural Sciences and Technologies, Universty of Niğde, 51200 Niğde, Turkey
}

\section{A R T I C LE INFO}

\section{Article history:}

Received 12 March 2015

Accepted 18 March 2015

Available online, ISSN: 2148-127X

Keywords:

Karayaka

Lamb

Slaughter weight

Carcass traits

Dissection

$\frac{{ }^{\text {"Corresponding Author: }}}{\text { E-mail: yuksel.aksoy@gop.edu.tr }}$

\begin{abstract}
A B S T R A C T
The present study was conducted to investigate the carcass traits of Karayaka lambs slaughtered at different slaughter weights (SWs) and to find out optimum SWs. Male Karayaka lambs with $20 \mathrm{~kg}$ live weight $(\mathrm{n}=30)$ constituted the animal material of the study. Lambs were randomly divided into five SW groups; 30 (GI; $n=6), 35$ (GII; $n=6$ ), 40 (GIII; n=6); 45 (GIV; n=6) and $50(\mathrm{GV} ; \mathrm{n}=6) \mathrm{kg}$. Lamb fattening feed (concentrate feed, ad libitum) and forage (lentil straw, $100 \mathrm{~g} / \mathrm{lamb} / \mathrm{day}$ ) were used as the feed material. Lambs were sent to slaughter at target SWs. Following the slaughter, non-carcass components, tailless hot and cold carcass weights were taken. Carcasses were separated into six sections as leg, foreleg, back, loin, neck and others. Physical dissection was performed to investigate carcass composition. Only the differences in carcass dressing and skin percentages of slaughter groups were not found to be significant. Increasing carcass fat percentages and decreasing carcass lean and bone percentages were observed with increasing SWs. Considering the consumer preferences, current findings revealed that Karayaka lambs should be sent to slaughter at weights between 30-35 kg. However, considering the red meat deficit of the country, current market conditions and producer preferences, the optimum SW for Karayaka lambs were recommended to be between 40$45 \mathrm{~kg}$.
\end{abstract}

\section{Entansif Şartlarda Yetiștirilen Karayaka Erkek Kuzuların Kesim ve Karkas Özellikleri Üzerine Farklı Kesim Ağırı̆ı̆ının Etkisi}

\section{A K A L E B İ L G İ S İ}

Geliş 12 Mart 2015

Kabul 18 Mart 2015

Çevrimiçi baskı, ISSN: 2148-127X

Anahtar Kelimeler:

Karayaka

Kuzu

Kesim ağırlığ

Karkas özellikleri

Diseksiyon

"Sorumlu Yazar:

E-mail: : yuksel.aksoy@gop.edu.tr

\section{Ö Z E T}

$\mathrm{Bu}$ araştırma, farklı kesim ağırlıklarında Karayaka kuzuların karkas özelliklerinin araştırılması ve kuzularda uygun kesim ağırlığının belirlenmesi amacıyla yapılmıștır. Araştırma hayvan materyalini, $20 \mathrm{~kg}$ canlı ağırlığında Karayaka erkek kuzular $(\mathrm{n}=30)$ oluşturmuştur. Kuzular 30 (GI; n=6), 35 (GII; n=6), 40 (GIII; n=6); 45 (GIV; n=6) ve 50 $(\mathrm{GV} ; \mathrm{n}=6) \mathrm{kg}$. olmak üzere beş farklı kesim ağırlı̆̆ 1 grubuna rastgele dağıtılmıştır. Besi süresince yem materyali olarak kuzu besi yemi (ad libitum) ve mercimek samanı (100 g/kuzu/gün) kullanılmıştır. Hedeflenen kesim canlı ağırlığına ulaşılan kuzular kesime gönderilmiştir. Kesim sonrası sakatat ağırlıkları, kuyruksuz sıcak ve soğuk karkas ağırlıkları alınmıştır. Karkaslar but, kol, sırt, bel, boyun ve diğerleri olmak üzere altı parçaya ayrılmıştır. Kuzularda karkas kompozisyonunu araştırmak amacıyla fiziksel olarak diseksiyon yapılmıştır. Araştırmada, kesim özelliklerine ait oranlardan sadece karkas randımanları ve deri oranları bakımından kesim grupları arasında farklar önemsiz bulunmuştur. Kesim ağırlığın artışıyla karkas yağ oranı artmış, karkas et ve kemik oranı azalmıştır. Sonuç olarak, tüketicilerin yağsız eti tercih etmeleri durumunda Karayaka kuzular 30-35 kg arasında kesime sevk edilmeleri uygundur. Ancak, ülkemizdeki kırmızı et açığı ve pazar durumu ile yetiştirici tercihleri de göz önünde bulundurulduğunda bugünkü şartlarda en uygun kesim aralığının 40-45 kg arasında olabileceği ifade edilebilir. 


\section{Introduction}

Humans should consume a certain amount of red meat daily for a sufficient and balanced nutrition. Not only the amount, but also the quality of red meat should meet daily sufficient and balanced nutritional needs of humans. Prolonged fattening periods may deteriorate carcass morphology and thus the carcass quality of lambs. Although low carcass fat percentages reduce the fattening costs, fats preserve carcass freshness and prevent loss and color problems. However, rapid increase in fat storage slows down muscle growth and development. Prolonged fattening periods beyond a certain period ultimately results in excessive fattening (Tekel et al., 2007). Therefore, optimum slaughter weights breeds should be determined for indigenous sheep breeds

Karayaka lambs are widely reared along Black Sea coastline. They constituted the subject matter of the present study and they are breeds indigenous of Turkey (Akçapınar, 2000; Kaymakçı, 2006). The breed is primarily reared for meat, then for milk and wool (Kaymakçı, 2006). They are known with their small sizes and low yields. Mature live weights of Karayaka rams vary between $40-50 \mathrm{~kg}$ and live weights of sheep vary between 35-40 kg (Akçapınar, 2000; Kaymakç1, 2006). Average fertility rates are around 1.00-1.29 (Baş et al., 1993; Olfaz and Saylam, 1996; Akçapınar et al., 2002a; Ünal et al., 2003). Previous studies revealed the lactation periods of Karayaka sheep as between 100-160 days and lactation milk yields as between 60-90 kg (Akçapınar, 2000; Kaymakç1, 2006).

There are several previous studies about slaughter and carcass characteristics of Karayaka lambs and their crossbreds (Olfaz, 1997; Oğan, 2000; Akçapınar et al., 2002b; Sen et al., 2011). However, a comprehensive study has not be carried out about slaughter and carcass traits of Karayaka lambs reared under intensive production systems and slaughtered at different slaughter weights (SWs). Therefore, the present study was conducted to investigate the slaughter and carcass traits of Karayaka lambs at different SWs and to find out the optimum SW.

\section{Materials and Methods}

The present study was conducted out at the experimental farm of Gaziosmanpaşa University Agricultural Faculty, Tokat, Turkey, $\left(40^{\circ} 31^{\prime} \mathrm{N}, 36^{\circ} 53^{\prime} \mathrm{E}\right.$, and $650 \mathrm{~m}$ above the sea level). The study was approved by Ethical Committee of Gaziosmanpaşa University for Experimental Animals (with the protocol number: 2011/046). Male lambs born as singleton, average $20 \mathrm{~kg}$ live weight $(n=36)$ constituted the animal material of the study. The lambs were reared with their dams and had ewes' milk from birth to weaning, with an age of 90 days. Lambs were randomly assigned to one of five following SWs: 30 (GI; n=6), 35 (GII; n=6), 40 (GIII; n=6); 45 $(\mathrm{GIV} ; \mathrm{n}=6)$ and $50(\mathrm{GV} ; \mathrm{n}=6) \mathrm{kg}$ of live weight. Before fattening period, lambs were treated for parasites, drenched with anthelmintic preparation (Triclabendazole $12 \mathrm{mg} / \mathrm{kg}$; Levamisole $7.5 \mathrm{mg} / \mathrm{kg}$ ) and housed together in $5 \times 8 \mathrm{~m}$ pens. Lamb fattening feed (concentrate feed) and forage (lentil straw) were supplied as the feed material. Concentrate feed, mineral stone and fresh water were supplied ad libitum throughout the fattening period, whereas lentil straw was supplied only $100 \mathrm{~g} / \mathrm{lamb} /$ day during the experimental period. The chemical composition of the feed supplements is provided in Table 1.

The lambs with desired SWs were taken into private pens. Animals were not fed for 12 hours ahead of the slaughter; they were transported to a local licensed abattoir for 10 minutes. After holding in paddock of slaughterhouse for 2 hours, they were slaughtered following standard commercial slaughter procedures (TSI, 1987). Lambs were brought to slaughter within $\pm 1 \mathrm{~kg}$ of the expected SWs. Following the slaughter, the weights of hot carcass, skin, head, feet, omental-mesenteric fats and visceral organs (heart, liver, lungs plus trachea, spleen and kidneys) were recorded and the carcasses were cooled at $+4{ }^{\circ} \mathrm{C}$ for $24 \mathrm{~h}$ and then cold carcass weight was recorded. The hot, cold dressing (tailless) and non-carcass components percentages were calculated on SW and the kidneys percentages were expressed as a percentage of cold carcass weight.

Carcass measurements were taken over cold carcasses (Russo et al., 2003; Vacca et al., 2008; Carrasco et al., 2009; Teklebrhan et al., 2012). Carcass conformation coefficients were calculated in accordance with Russo et al. (2003), Peña et al. (2005), Vacca et al. (2008), and Önenç et al. (2009).

Kidneys, perinephric-pelvic fat and tail fat were separated before jointing. Cold carcasses were separated into neck, leg, foreleg, back, loin and other sections in accordance with carcass separation method described in Akçapınar (1981). Following the separation, back fat thickness was measured between $12^{\text {th }}$ and $13^{\text {th }}$ ribs (over $m$. longissimus et thoracis (MLD)) with a digital caliper. The MLD muscle cut out from this section was drawn over a tracing paper and muscle area was measured with a digital planimeter (Yakan and Ünal, 2010). Weights of carcass sections were measured with a precise balance $( \pm 1.0 \mathrm{~g})$. Following the weighing, physical dissection was performed to determine lean, fat and bone percentages of each section (Öztürk et al., 2012).

\section{Statistical Analyses}

In order to determine the effects of SWs on slaughter and carcass traits one-way ANOVA was performed by using SPSS (1999) software. Duncan's test was used to present the differences among the means (Düzgüneş et al., 1987).

Table 1 The chemical composition of concentrate feed and forage (lentil straw)

\begin{tabular}{l|cc}
\hline \multicolumn{1}{c|}{ Nutrient content } & $\begin{array}{c}\text { Concentrate } \\
\text { feed }\end{array}$ & $\begin{array}{c}\text { Lentil } \\
\text { straw }\end{array}$ \\
\hline Dry matter (\%) & 92.0 & 91.3 \\
Crude protein (\%) & 20.63 & 5.78 \\
ADF (\%) & 26.39 & 55.59 \\
NDF (\%) & 37.96 & 56.29 \\
Crude oil (\%) & 2.60 & 1.49 \\
Crude ash (\%) & 10.40 & 9.60 \\
Metabolic energy (kcal/kg) & 2658 & 2012 \\
\hline \multicolumn{2}{l}{ ADF: Acid Detergent Fiber; NDF: Neutral Detergent Fiber }
\end{tabular}




\section{Results}

The results for slaughter traits according to SWs are provided in Table 2. Except for hot, cold dressing and skin percentages, significant differences were observed in other percentages of slaughter groups $(\mathrm{P}<0.05)$. The highest hot and cold dressing percentages $(49.70 \%$ and $48.66 \%$ ) were obtained from GIV and the lowest dressing percentages $(46.73 \%$ and $45.34 \%)$ were obtained from GI slaughter weight group.

The mean value for percentages of carcass cuts, carcass measurements and indices according to SW groups are summarized in Table 3 . The differences in carcass length $(\mathrm{P}<0.001)$, external hindquarter length $(\mathrm{P}<0.001)$, pelvic limb length $(\mathrm{P}<0.01)$, hindquarter perimeter $(\mathrm{P}<0.001)$, hindquarter width $(\mathrm{P}<0.001)$ and chest width $(\mathrm{P}<0.01)$ of $\mathrm{SW}$ groups were found to be significant. Increasing carcass compactness was observed with increasing SWs of Karayaka lambs $(\mathrm{P}<0.001)$. However, carcass compactness coefficients of the groups GIV and GV were similar to each other. The differences in carcass and leg conformation of slaughter groups were not found to be significant $(\mathrm{P}>0.05)$. Except for foreleg $(\mathrm{P}<0.01)$ and neck $(\mathrm{P}<0.05)$ percentages, differences in carcass cut percentages of slaughter groups were also found to be insignificant $(\mathrm{P}>0.05)$.

The means for lean, fat and bone percentages of carcass and cuts are provided in Table 4 . The differences in carcass fat $(\mathrm{P}<0.001)$, bone $(\mathrm{P}<0.001)$, lean/fat $(\mathrm{P}<0.01)$ and lean/bone $(\mathrm{P}<0.001)$ percentages of slaughter groups were found to be significant. The differences in fat and bone percentages of entire carcass cuts of slaughter groups were also found to be significant $(\mathrm{P}<0.05)$. Only the differences in loin lean percentages of slaughter groups were also found to be significant $(\mathrm{P}<0.01)$.

\section{Discussion and Conclusion}

Carcass dressing percentage is a significant factor for meat production and carcass quality (Tufan and Akmaz, 2001). Increasing hot and cold carcass dressing percentages were observed in this study with increasing SWs (Table 2). The cold carcass dressing percentage of GV slaughter group was lower than the dressing percentage value of GIV slaughter group. Such a case may be resulted from increasing skin and head percentages through increasing SWs from 45 to $50 \mathrm{~kg}$ live weight. Cold carcass dressing percentages of Karayaka lambs of the present study were similar to values reported for the same breed by Oğan (2000) (at $51 \mathrm{~kg} \mathrm{SW}$; 47.91\%) and Akçapınar et al. (2002b) (at $40 \mathrm{~kg} \mathrm{SW}$; $47.15 \%$ ). But they were different from Bandirma-I (at 41 $\mathrm{kg} \mathrm{SW} ; 50.19 \%$ ) and Bandirma-II (at $40 \mathrm{~kg} \mathrm{SW} ; 50.63 \%$ ) crossbred lambs (Ceyhan et al., 2008).

Except for skin percentage, the differences in other non-carcass components of slaughter groups were found to be significant. Similar to current findings, Teke and Ünal (2009) also reported insignificant effects of SWs on skin percentages. However, Perez et al. (2007), and Yakan and Ünal (2010) contrarily indicated the significant effects of SWs on skin percentages. The highest skin and head percentages of the present study were obtained from GV slaughter group. Among the indigenous breeds of Turkey, Karayaka has long hair slice and horn (Akçapınar, 2000) which may explain the high skin and head percentages of the breed. Head and testicles percentages increased but feet, liver, kidney and heart percentages decreased with increasing SWs of the present study. Similar to current findings, Teke and Ünal (2009), and Yakan and Ünal (2010) in a study about the effects of SWs on some carcass traits of Akkaraman, Morkaraman, Turkish Merino and Bafra (Sakız x Karayaka $\left(\mathrm{B}_{1}\right)$ ) lambs, reported decreased non-carcass components with increasing SWs.

Table 2 Means for slaughter traits of lambs

\begin{tabular}{|c|c|c|c|c|c|c|c|}
\hline \multirow[t]{2}{*}{ Traits } & \multicolumn{5}{|c|}{ Slaughter weight groups } & \multirow{3}{*}{$\mathrm{MSE}^{1}$} & \multirow{3}{*}{$\mathrm{P}$} \\
\hline & GI & GII & GIII & GIV & $\mathrm{GV}$ & & \\
\hline Slaughter weight (kg) & 30.15 & 35.58 & 40.40 & 45.12 & 50.16 & & \\
\hline Age at final weight (day) & 42.29 & 58.87 & 77.50 & 96.33 & 110.60 & & \\
\hline Hot carcass weight $(\mathrm{kg})$ & $14.03^{\mathrm{e}}$ & $16.97^{\mathrm{d}}$ & $19.45^{\mathrm{c}}$ & $22.43^{\mathrm{b}}$ & $24.55^{\mathrm{a}}$ & 0.30 & $* * *$ \\
\hline Cold carcass weight (kg) & $13.61^{\mathrm{e}}$ & $16.72^{\mathrm{d}}$ & $19.13^{\mathrm{c}}$ & $21.96^{\mathrm{b}}$ & $23.95^{\mathrm{a}}$ & 0.31 & $* * *$ \\
\hline Hot dressing percentage $(\%)$ & 46.73 & 47.67 & 48.17 & 49.70 & 48.27 & 0.78 & - \\
\hline Cold dressing percentage $(\%)$ & 45.34 & 46.50 & 47.16 & 48.66 & 47.09 & 0.80 & - \\
\hline \multicolumn{8}{|c|}{ Non-carcass components (as \% of slaughter weight) } \\
\hline Head & $5.14^{\mathrm{bc}}$ & $4.94^{\mathrm{c}}$ & $5.17^{\mathrm{bc}}$ & $5.55^{\mathrm{ab}}$ & $5.72^{\mathrm{a}}$ & 0.17 & $* *$ \\
\hline Skin & 13.91 & 14.22 & 13.49 & 13.60 & 14.79 & 0.26 & - \\
\hline Feet & $2.65^{\mathrm{a}}$ & $2.45^{\mathrm{b}}$ & $2.24^{\mathrm{c}}$ & $2.11^{\mathrm{d}}$ & $2.12^{\mathrm{d}}$ & 0.01 & $* * *$ \\
\hline Liver & $2.10^{\mathrm{a}}$ & $2.02^{\mathrm{a}}$ & $1.81^{\mathrm{b}}$ & $1.74^{\mathrm{b}}$ & $1.65^{\mathrm{b}}$ & 0.03 & $* *$ \\
\hline Spleen & $0.15^{\mathrm{ab}}$ & $0.14^{\mathrm{abc}}$ & $0.12^{\mathrm{c}}$ & $0.14^{\mathrm{bc}}$ & $0.16^{\mathrm{a}}$ & 0.01 & $*$ \\
\hline Kidneys & $0.37^{\mathrm{a}}$ & $0.34^{\mathrm{ab}}$ & $0.31^{\mathrm{bc}}$ & $0.30^{\mathrm{bc}}$ & $0.29^{c}$ & 0.01 & $* *$ \\
\hline Heart & $0.44^{\mathrm{a}}$ & $0.45^{\mathrm{a}}$ & $0.40^{\mathrm{ab}}$ & $0.38^{\mathrm{b}}$ & $0.39^{\mathrm{b}}$ & 0.01 & $*$ \\
\hline Lungs & $0.87^{\mathrm{d}}$ & $0.92^{\text {cd }}$ & $1.05^{\mathrm{bc}}$ & $1.09^{\mathrm{ab}}$ & $1.23^{\mathrm{a}}$ & 0.02 & $* * *$ \\
\hline Testicles & $0.20^{\mathrm{b}}$ & $0.33^{\mathrm{b}}$ & $0.49^{\mathrm{a}}$ & $0.48^{\mathrm{a}}$ & $0.55^{\mathrm{a}}$ & 0.01 & $* * *$ \\
\hline Omental-mesenteric fat & $0.81^{\mathrm{c}}$ & $1.11^{\mathrm{bc}}$ & $1.33^{\mathrm{ab}}$ & $1.57^{\mathrm{a}}$ & $1.41^{\mathrm{ab}}$ & 0.06 & $* * *$ \\
\hline Back fat thickness (mm) & $2.78^{\mathrm{c}}$ & $4.39^{\mathrm{b}}$ & $4.42^{\mathrm{b}}$ & $6.57^{\mathrm{a}}$ & $7.25^{\mathrm{a}}$ & 0.19 & $* * *$ \\
\hline Eye muscle area $\left(\mathrm{cm}^{2}\right)$ & $10.67^{\mathrm{c}}$ & $12.51^{\mathrm{b}}$ & $12.96^{\mathrm{b}}$ & $15.04^{\mathrm{a}}$ & $15.09^{\mathrm{a}}$ & 0.32 & $* * *$ \\
\hline
\end{tabular}

${ }^{1}$ Mean Standard Error, -: Non-significant, *: $\mathrm{P}<0.05, * *: \mathrm{P}<0.01, * * *: \mathrm{P}<0.001$

a,b,c,d: The differences indicated by different letters on the same line are significant 
Table 3 Means for carcass traits of lambs

\begin{tabular}{|c|c|c|c|c|c|c|c|}
\hline \multirow{2}{*}{ Traits } & \multicolumn{5}{|c|}{ Slaughter weight groups } & \multirow{2}{*}{$\mathrm{MSE}^{1}$} & \multirow{2}{*}{$\mathrm{P}$} \\
\hline & GI & GII & GIII & GIV & $\mathrm{GV}$ & & \\
\hline \multicolumn{8}{|l|}{ Carcass measurements $(\mathrm{cm})$} \\
\hline Carcass length & $60.22^{c}$ & $63.43^{\mathrm{b}}$ & $64.86^{\mathrm{b}}$ & $64.73^{b}$ & $68.40^{\mathrm{a}}$ & 0.39 & $* * *$ \\
\hline External hindquarter length & $35.75^{\mathrm{c}}$ & $36.60^{\mathrm{c}}$ & $38.06^{\mathrm{b}}$ & $38.68^{\mathrm{ab}}$ & $39.40^{\mathrm{a}}$ & 0.19 & $* * *$ \\
\hline Pelvic limb length & $36.27^{\mathrm{c}}$ & $37.45^{\mathrm{bc}}$ & $38.11^{\mathrm{b}}$ & $39.04^{\mathrm{ab}}$ & $40.00^{\mathrm{a}}$ & 0.49 & $* *$ \\
\hline Chest width & $24.90^{\mathrm{b}}$ & $26.05^{\mathrm{b}}$ & $27.58^{\mathrm{a}}$ & $28.28^{\mathrm{a}}$ & $28.62^{\mathrm{a}}$ & 0.20 & $* * *$ \\
\hline Hindquarter perimeter & $56.82^{\mathrm{d}}$ & $60.17^{\mathrm{c}}$ & $61.91^{\mathrm{bc}}$ & $63.24^{\mathrm{b}}$ & $66.95^{\mathrm{a}}$ & 0.42 & $* * *$ \\
\hline Hindquarter width & $20.51^{\mathrm{c}}$ & $21.92^{\mathrm{b}}$ & $22.60^{\mathrm{ab}}$ & $23.02^{\mathrm{a}}$ & $23.17^{\mathrm{a}}$ & 0.13 & $* * *$ \\
\hline \multicolumn{8}{|l|}{ Carcass indices } \\
\hline Compactness (kg/cm) & $0.22^{\mathrm{d}}$ & $0.25^{\mathrm{c}}$ & $0.29^{b}$ & $0.33^{\mathrm{a}}$ & $0.34^{\mathrm{a}}$ & 0.01 & $* * *$ \\
\hline Carcass conformation & 0.41 & 0.41 & 0.42 & 0.44 & 0.41 & 0.01 & - \\
\hline Leg conformation & 0.56 & 0.58 & 0.59 & 0.58 & 0.57 & 0.01 & - \\
\hline \multicolumn{8}{|c|}{ Individual cuts in left half carcass (out of 100) } \\
\hline Leg & 36.05 & 35.06 & 36.93 & 35.60 & 35.68 & 0.50 & - \\
\hline Foreleg & $18.57^{\mathrm{a}}$ & $17.33^{\mathrm{b}}$ & $17.02^{\mathrm{b}}$ & $16.71^{\mathrm{b}}$ & $17.11^{\mathrm{b}}$ & 0.33 & $* *$ \\
\hline Loin & 6.71 & 6.80 & 7.01 & 7.29 & 6.91 & 0.15 & - \\
\hline Back & 9.49 & 9.79 & 9.46 & 9.39 & 9.09 & 0.29 & - \\
\hline Neck & $7.24^{\mathrm{b}}$ & $7.34^{\mathrm{b}}$ & $7.65^{\mathrm{ab}}$ & $8.61^{\mathrm{a}}$ & $8.59^{\mathrm{a}}$ & 0.32 & $*$ \\
\hline Breast+flank & 22.44 & 23.19 & 22.97 & 23.30 & 22.32 & 0.29 & - \\
\hline Tail fat & 2.61 & 2.93 & 3.39 & 3.74 & 3.80 & 0.13 & - \\
\hline
\end{tabular}

$\mathrm{a}, \mathrm{b}, \mathrm{c}, \mathrm{d}$ : The differences indicated by different letters on the same line are significant

Table 4 Means for carcass lean, fat and bone percentages of lambs

\begin{tabular}{|c|c|c|c|c|c|c|c|}
\hline \multirow{2}{*}{ Traits } & \multicolumn{5}{|c|}{ Slaughter weight groups } & \multirow{2}{*}{$\mathrm{MSE}^{1}$} & \multirow{2}{*}{$\mathrm{P}$} \\
\hline & GI & GII & GIII & GIV & GV & & \\
\hline \multicolumn{8}{|c|}{ Composition of the left carcass (out of 100) } \\
\hline Lean & 52.83 & 49.45 & 50.00 & 48.51 & 48.95 & 0.49 & - \\
\hline Fat & $30.95^{\mathrm{b}}$ & $36.05^{\mathrm{a}}$ & $37.54^{\mathrm{a}}$ & $40.20^{\mathrm{a}}$ & $39.80^{\mathrm{a}}$ & 0.61 & $* * *$ \\
\hline Bone & $16.20^{\mathrm{a}}$ & $14.49^{\mathrm{b}}$ & $12.45^{\mathrm{c}}$ & $11.27^{\mathrm{c}}$ & $11.24^{\mathrm{c}}$ & 0.22 & $* * *$ \\
\hline Lean/Fat & $1.73^{\mathrm{a}}$ & $1.39^{\mathrm{b}}$ & $1.33^{\mathrm{b}}$ & $1.21^{\mathrm{b}}$ & $1.24^{\mathrm{b}}$ & 0.04 & $* *$ \\
\hline Lean/Bone & $3.28^{\mathrm{b}}$ & $3.42^{\mathrm{b}}$ & $4.02^{\mathrm{a}}$ & $4.31^{\mathrm{a}}$ & $4.35^{\mathrm{a}}$ & 0.05 & $* * *$ \\
\hline \multicolumn{8}{|c|}{ Composition of the left carcass cuts (out of 100) } \\
\hline \multicolumn{8}{|l|}{ Leg } \\
\hline Lean & 53.97 & 51.13 & 49.12 & 50.03 & 50.81 & 1.29 & - \\
\hline Fat & $14.94^{\mathrm{a}}$ & $12.91^{\mathrm{b}}$ & $11.47^{\mathrm{bc}}$ & $10.38^{\mathrm{c}}$ & $11.22^{\mathrm{c}}$ & 0.52 & $* *$ \\
\hline Bone & $31.08^{\mathrm{b}}$ & $35.94^{\mathrm{a}}$ & $39.40^{\mathrm{a}}$ & $39.57^{\mathrm{a}}$ & $37.96^{\mathrm{a}}$ & 1.44 & $* * *$ \\
\hline \multicolumn{8}{|l|}{ Foreleg } \\
\hline Lean & 55.48 & 52.81 & 53.31 & 52.57 & 53.00 & 0.98 & - \\
\hline Fat & $17.49^{\mathrm{a}}$ & $15.85^{\mathrm{ab}}$ & $14.71^{b c}$ & $13.44^{\mathrm{c}}$ & $13.91^{\mathrm{c}}$ & 0.52 & $* * *$ \\
\hline Bone & $27.02^{\mathrm{b}}$ & $31.32^{\mathrm{a}}$ & $31.96^{\mathrm{a}}$ & $33.98^{\mathrm{a}}$ & $33.08^{\mathrm{a}}$ & 1.31 & $* *$ \\
\hline \multicolumn{8}{|l|}{ Loin } \\
\hline Lean & $54.66^{\mathrm{a}}$ & $51.62^{\mathrm{ab}}$ & $49.36^{\mathrm{b}}$ & $43.58^{\mathrm{c}}$ & $48.89^{\mathrm{b}}$ & 1.67 & $* *$ \\
\hline Fat & $12.44^{\mathrm{a}}$ & $11.21^{\mathrm{a}}$ & $9.49^{b}$ & $8.21^{b}$ & $8.81^{\mathrm{b}}$ & 0.52 & $* * *$ \\
\hline Bone & $32.89^{c}$ & $37.15^{\mathrm{bc}}$ & $41.14^{\mathrm{b}}$ & $48.20^{\mathrm{a}}$ & $42.28^{\mathrm{ab}}$ & 2.05 & $* * *$ \\
\hline \multicolumn{8}{|l|}{ Back } \\
\hline Lean & 42.82 & 38.56 & 41.08 & 38.20 & 43.54 & 1.71 & - \\
\hline Fat & $18.95^{\mathrm{a}}$ & $16.73^{\mathrm{b}}$ & $15.06^{\mathrm{bc}}$ & $13.51^{\mathrm{cd}}$ & $12.77^{\mathrm{d}}$ & 0.69 & $* * *$ \\
\hline Bone & $38.22^{\mathrm{b}}$ & $44.68^{\mathrm{a}}$ & $43.84^{\mathrm{ab}}$ & $48.27^{\mathrm{a}}$ & $43.68^{a b}$ & 1.97 & $*$ \\
\hline \multicolumn{8}{|l|}{ Neck } \\
\hline Lean & 47.02 & 41.76 & 45.82 & 44.47 & 45.26 & 1.83 & - \\
\hline Fat & $17.84^{\mathrm{a}}$ & $14.58^{\mathrm{b}}$ & $14.64^{\mathrm{b}}$ & $11.55^{\mathrm{c}}$ & $10.28^{\mathrm{c}}$ & 0.71 & $* * *$ \\
\hline Bone & $35.13^{\mathrm{b}}$ & $43.65^{\mathrm{a}}$ & $39.53^{\mathrm{ab}}$ & $43.96^{\mathrm{a}}$ & $44.44^{\mathrm{a}}$ & 1.96 & $* *$ \\
\hline \multicolumn{8}{|l|}{ Breast+Flank } \\
\hline Lean & 44.31 & 42.06 & 43.10 & 41.53 & 41.89 & 1.24 & - \\
\hline Fat & $14.25^{\mathrm{a}}$ & $11.88^{\mathrm{b}}$ & $9.51^{\mathrm{c}}$ & $8.86^{\mathrm{c}}$ & $8.51^{\mathrm{c}}$ & 0.59 & $* * *$ \\
\hline Bone & $41.42^{\mathrm{b}}$ & $46.05^{\mathrm{ab}}$ & $47.37^{\mathrm{a}}$ & $49.59^{\mathrm{a}}$ & $49.59^{\mathrm{a}}$ & 1.62 & $* *$ \\
\hline
\end{tabular}

${ }^{1}$ Mean Standard Error, -: Non-significant, *: $\mathrm{P}<0,05$, **: $\mathrm{P}<0,01$, ***: $\mathrm{P}<0,00$

a,b,c,d: The differences indicated by different letters on the same line are significant 
Back fat thickness, MLD sectional areas and lean, bone, fat percentages of carcass cuts are the significant quality parameters for carcasses. While larger MLD sectional areas yields of the lambs percentages and thicker back fat are thickness the indicators of poor carcass quality (Şahin, 2002). Ceyhan et al. (2008) reported that MLD sectional area is an important characteristic for determining the valuable meat content of the carcass. MLD sectional area results of Karayaka lambs of the present study were lower than the Bandirma-I $\left(18.71 \mathrm{~cm}^{2}\right)$ and Bandirma-II $\left(17.39 \mathrm{~cm}^{2}\right)$ crossbred lambs. Increasing MLD areas were observed with increasing SWs of Karayaka lambs. This result was in agreement with the results obtained by Perez et al. (2007) working on suckling lambs from four different genotypes (Suffolk Down, Merino Precoz Aleman, Suffolk Down x Merino Precoz Aleman crosses and Suffolk Down x Corrriedale slaughtered at weights 10 and $15 \mathrm{~kg}$ ) and Yakan and Ünal (2010) working on Bafra (Sak1z x Karayaka $\left(B_{1}\right)$ ) lambs slaughtered at 30, 35, 40 and $45 \mathrm{~kg}$ live weights.

Carcass compactness coefficient was calculated as the ratio of cold carcass weight to carcass length. The differences in carcass compactness coefficients of slaughter groups were found to be significant (Table 3). Except for $50 \mathrm{~kg} \mathrm{SW}$ of the present study, compactness coefficients were similar to values reported by Yakan and Ünal (2010) for Bafra (Sakız x Karayaka $\left(B_{1}\right)$ ) lambs. Önenç et al. (2012) reported carcass compactness value of Sak1z lambs (at $50 \mathrm{~kg} \mathrm{SW}$ ) as 0.34 . This value was similar to value observed for Karayaka lambs at the same SW. The differences in carcass conformation and leg conformation values of slaughter groups of Karayaka lambs were not found to be significant. The leg conformation of GV slaughter group was similar to the value reported by Önenç et al. (2012) for Sakız lambs at the same SW.

In lamb carcasses, the percentages of other sections as leg, back, loin and foreleg are desired to be high (Altın et al., 2005). The percentages significantly affect the quality and quantity of the meat to be obtained from the carcass. In general, decreasing leg, back and foreleg percentages but increasing loin percentages were observed in this study with increasing SWs.

Leg percentages of slaughter groups were higher than the values reported by Olfaz (1997) for Karayaka lambs and by Altın et al. (2005), and Karabacak (2007) for Kivircik lambs at the same SWs. Tekin (1991) slaughtered Turkish Merino lambs at 35, 40 and $45 \mathrm{~kg}$ weights and reported leg percentages as $35.44,34.67$, and $34.44 \%$, respectively. Tailless carcass leg ratio of the present study was similar to value reported by Tekin (1991) for Turkish Merino lambs at the same SW. In studies carried out with intensively reared thin tailed lambs slaughtered at 30-45 kg live weights, Tekin (1991), Köycü and Özder (2004), Altın et al. (2005), and Karabacak (2007) reported similar carcass foreleg percentages with the lower limit values and higher values than upper limit values of the present study for Karayaka lambs. Carcass back percentage of the present study was higher than the values reported by Tekin (1991) for Turkish Merino lambs (8.06-8.46\%) (at 35, 40 and $45 \mathrm{~kg}$ SWs), by Oğan (2000) for Karayaka lambs (at $50 \mathrm{~kg} \mathrm{SW}$ )
(8.82\%), by Yakan and Ünal (2010) for Bafra (Sak1z x Karayaka $\left(\mathrm{B}_{1}\right)$ ) lambs; lower than the values reported by Akçapınar et al. (2002b) for Bafra (Sakız x Karayaka $\left(\mathrm{B}_{1}\right)$ ) lambs $(11.42 \%$ ) (at $40 \mathrm{~kg} \mathrm{SW}$ ). Carcass loin percentages $(6.71-7.29 \%)$ of the present study were similar to values reported by Tufan and Akmaz (2001) and Şahin (2002) for local sheep breeds (slaughtered at 30,35 , and $40 \mathrm{~kg}$ ) and were lower than the values reported by Tekin (1991) for Turkish Merino lambs (8.06$8.46 \%)(35,40$, and $45 \mathrm{~kg} \mathrm{SW})$.

Determination of total lean, fat and bone percentages through dissection without deteriorating the usability of the meat is a significant issue to find out optimum SWs for quality carcass and lean meat (Demir, 2001). Carcass lean and bone percentages decreased but fat percentage increased in this study with increasing SWs (Table 4). Similarly, Tufan and Akmaz (2001), and Şahin (2002) carried out studies with fat tailed sheep breeds and reported higher fat and lower lean and bone percentages at higher SWs. Also, some studies reported that meat and bone percentages decreased with increasing carcass weights (Díaz et al., 2003; Perez et al., 2007; Santos et al., 2007). Karayaka is a small-size local breed. Sañudo et al. (1998) reported that when lambs were at slaughtering age, small breeds had lower weights and more fat than large breeds. Carcass fat percentages of Karayaka lambs at all SWs were lower than the values reported by Tufan and Akmaz (2001), Şahin (2002), Yakan and Ünal (2010), and Tekin (1991) for intensively reared Güney Karaman, Akkaraman, Bafra (Sakız x Karayaka $\left(\mathrm{B}_{1}\right)$ ) and Turkish Merino lambs (at 30, 3540 and $45 \mathrm{~kg} \mathrm{SWs).} \mathrm{Such}$ differences may be because of genotypes, tails and yields of the lambs. Olfaz (1997) reported the lean, bone and fat percentages of Karayaka lambs fattened for 63 days (at 29 $\mathrm{kg} \mathrm{SW)} \mathrm{as} \mathrm{51.16,} \mathrm{21.66,} \mathrm{and} \mathrm{27.33 \% ,} \mathrm{respectively.}$ Carcass lean percentages of the present study were lower than the values reported by Santos-Silva et al. (2002) for Merino Branco lambs (slaughtered at 24 and $30 \mathrm{~kg}$ live weight), by Díaz et al. (2003) for Manchego lambs (at 10, 12, and $14 \mathrm{~kg} \mathrm{SW}$ ), by Perez et al. (2007) for four different lamb genotypes (slaughtered at 10 and $15 \mathrm{~kg}$ ), and higher than the values reported by Tufan and Akmaz (2001) for Güney Karaman and Kangal Akkaraman (at 35 and $40 \mathrm{~kg} \mathrm{SW}$ ) lambs.

Carcass lean/fat ratios of Karayaka lambs decreased and lean/bone ratios increased with increasing SWs (Table 4). Previous researchers also reported decreasing carcass lean/fat ratios (Yakan and Ünal, 2010; Kremer et al., 2004) and increasing lean/bone ratios (Mahgoub and Lodge, 1994; Díaz et al., 2003; Santos-Silva et al., 2002) with increasing SWs. Such cases may be related to faster increases in carcass fat percentages than bone percentages with increasing SWs. Lean/fat ratios of Karayaka lambs at all SWs were lower and lean/bone ratios were higher than the values reported by Yakan and Ünal (2010) for Bafra (Sakız x Karayaka $\left(\mathrm{B}_{1}\right)$ ) lambs at the same SWs. Carcass lean/bone ratios of the present study were higher than the values reported by Santos et al. (2007) for Churra da Terra Quente lambs at different SWs $(<8 \mathrm{~kg}, 8-11 \mathrm{~kg}$, and $>11 \mathrm{~kg})(2.6,2.9$ and 3.1) and lean/fat ratios were lower than the values reported by Díaz et al. (2003) for Manchego. 
As to conclude, the highest cold carcass dressing percentage of Karayaka lambs at different SWs was observed in GIV SW group. The greatest increase in back fat thickness was observed between GIII-GIV SW groups. The highest carcass fat percentages and the lowest lean percentages were observed in GIV SW group. Decreasing lean/fat rations were observed with increasing SWs. Therefore, it was concluded considering the consumer preferences that Karayaka lambs should be slaughtered at SWs of between $30-35 \mathrm{~kg}$. However, considering the red meat deficit of Turkey, current market conditions and producer preferences, the optimum SW of Karayaka lambs should be between $40-45 \mathrm{~kg}$.

\section{Acknowledgements}

The present research was derived from the Ph.D. thesis entitled as "Determination of carcass and meat quality characteristics of Karayaka lambs with different slaughter weights". Authors wish to thank TUBITAK (Project no: TOVAG-1110848) and General Directorate of Agricultural Researches and Policies Public SmallHead Animal Breeding "Karayaka Sheep Breeding II University Nucleus Herd (Project no: 60KYK2005-01)" for their financial support the present research.

\section{References}

Akçapınar H. 1981. Researches on the meat production and carcass characteristics of Daglic, Akkaraman and Kivircik lambs slaughtered at different slaughter weights. FU Vet Fak Derg, 6: 165-184.

Akçapınar H. 2000. Koyun Yetiştiriciliği. Medisan Yayınevi. ISBN: 975-7774-05-7 Ankara.

Akçapınar H, Ünal N, Atasoy F, Özbeyaz C, Aytaç M. 2002a. Adaptation capability of Karayaka and Bafra (Chios $\mathrm{x}$ Karayaka $\left(B_{1}\right)$ ) genotypes reared in Lalahan Livestock Research conditions. Journal of Lalahan Livestock Research Institute, 42: 11-24.

Akçapınar H, Atasoy F, Ünal N, Aytaç M, Aylanç A. 2002b. The fattening and carcass characteristics of Bafra (Chios $\mathrm{x}$ Karayaka $\left(\mathrm{B}_{1}\right)$ ) lambs. Journal of Lalahan Livestock Research Institute, 42: 19-28.

Altın T, Karaca O, Cemal İ, Y1lmaz M, Yılmaz O. 2005. The fattening and carcass characteristics of Kivircik and Karya lambs. Journal of Animal Production, 46: 19-29.

Baş S, Olfaz M, Selçuk E. 1993. Erken yaşta damızlıkta kullanılan Karayaka anaç kuzuların bazı verim özellikleri. YYÜ Ziraat Fak Derg, 3: 73-86.

Carrasco S, Ripoll G, Panea B, Álvarez-Rodrìguez J, Joy M. 2009. Carcass tissue composition in light lambs: influence of feeding system and prediction equations. Livest Sci, 126: 112-121.

Ceyhan A, Hanoglu H, Sezenler T, Erdogan I. 2008. The 1mprovement studies on mutton sheep for Marmara Region conditions II. fattening and carcass characteristics of lambs. Bulgarian Journal of Agricultural Science, 14: 606-615.

Demir H. 2001. Phenotypic correlations among the amounts of total lean, fat and bone of Kivircik lamb carcasses and carcass joints. Eurasian Journal of Veterinary Sciences, 17: 67-72.

Díaz MT, Velasco S, Perez C, Lauzurica S, Huidobro F, Cañeque V. 2003. Physicochemicalcharacteristics of carcass and meat Manchego-breed suckling lambs slaughtered at differentweights. Meat Sci, 65: 1247-1255.

Düzgüneş O, Kesici T, Kavuncu O, Gürbüz F. 1987.Araştırma ve Deneme Metotları (İstatistik Metodları II). A.Ü. Ziraat Fakültesi Baskı Ünitesi, Ankara.
Karabacak A. 2007. Fattening performance and carcass characteristics of some fat tailed and thin tailed sheep breeds. Degree Diss, Selcuk University, Konya, Turkey.

Kaymakçı M. 2006. Ileri Koyun Yetistiriciligi. Publ. N. 1 Izmir Sheep-Goat Breeders Association, Izmir, Turkey.

Köycü E, Özder M. 2004. Fattening Performance, Slaughter and Carcass Characteristics of Turkgeldi Twin Lambs. Journal of Animal Production, 45: 33-38.

Kremer R, Barbato G, Castro L, Rista L, Roses L, Herrara V, Neirotti V. 2004. Effect of sire breed, year, sex, and weight, on carcass characteristics of lambs. Small Ruminant Res, 53: 117-124.

Mahgoub O, Lodge GA. 1994. Growth and body composition of Omani local sheep. 1. Live-weight growth and carcass and non-carcass characteristics. Anim Prod, 58: 365-372.

Olfaz M, Saylam SK. 1996. Karayaka Koyunlarının Mevsim Dışı Kuzulatılması İmkanları Üzerine Bir Araştırma. OMÜ Ziraat Fak Derg, 11: 1-8.

Olfaz M. 1997. Utilization possibilities from commun and exotic breeds to improve meat dressing percentages at the breeding of Karayaka sheep. Degree Diss, Ondokuz Mayıs University, Samsun, Turkey.

Oğan M. 2000. The fattening performance and carcass characteristics of Karayaka male lambs. Journal of Lalahan Livestock Research Institute, 40: 37-44.

Önenç A, Taşkın T, Kayaardı S, Özdoğan M, Metin K, Ateşlier ZBB, Arat Ö, Akşit H. 2009. A study on the evaluation of carcass and meat quality of common, slaughtered cattle and sheep breeds in Turkey under EUROP classification system (Project No: 1060722)

Önenç SS, Özdoğan M, Ataç FE, Taşkın T. 2012. Fattening performance and carcass traits of Chios male lambs fed under traditional and intensive feeding conditions. Trop Anim Health Prod, 44: 1057-1062.

Öztürk Y, Küçük M, Karslı MA. 2012. A Study on Growth, Slaughter and Carcass Traits of Morkaraman and Kıvırcik x Morkaraman $\left(\mathrm{F}_{1}\right)$ Lambs in Semi-Intensive Condition. Kafkas Univ Vet Fak Derg, 18: 1-6.

Peña F, Cano T, Domenech V, Alcalde MaJ, Martos J, Garc'iaMartinez A, Herrera M, Rodero E. 2005. Influence of sex, slaughter weight and carcass weight on "non-carcass" and carcass quality in segure na lambs. Small Ruminant Res, 60: 247-254.

Perez P, Manio M, Morales MS, Köbrich C, Bardon C, Pokmak C. 2007. Gender and slaughter weight effects on carcass quality traits of suckling lambs from four different genotypes. Small Ruminant Res, 70: 124-130.

Russo C, Preziuso G, Verità P. 2003. EU carcass classification systems: carcass and meat quality in light lambs. Meat Sci, 64: 411-416.

Santos-Silva J, Mendes IA, Bessa RJB. 2002. Effect of genotype, feeding system and slaughter weight on the quality of light lambs I. Growth, carcass composition and meat quality. Livest Prod Sci, 76: 17-25.

Santos VA, Silva SR, Mena EG, Azevedo JMT. 2007. Live weight and sex effets on carcassand meat quality of "Borrego terrincho-PDO" suckling lambs. Meat Sci, 77: 654-661.

Sañudo C, Sanchez A, Alfonso M. 1998. Small ruminant production systems and factors affecting lamb meat quality. Meat Sci, 49, Supplement 1, S29-S64.

Sen U, Sirin E, Ulutas Z, Kuran M. 2011. Fattening performance, slaughter, carcass and meat quality traits of Karayaka lambs. Trop Anim Health Prod, 43: 409-416.

SPSS 1999. SPSS for Windows, advanced statistics release 10. Chigago, IL, USA.

Şahin EH. 2002. Fattening performance, carcass characteristics and profitability of Akkaraman lambs at different slaughter weights . Degree Diss, Selcuk University, Konya, Turkey. 
Teke B, Ünal N. 2009. The effects of slaughter weight and sex on some slaughter traits of Akkaraman and Morkaraman and Turkish Merino lambs. Veterinary Journal of Ankara University, 56: 289-296.

Tekel N, Şireli HD, Vural ME. 2007. The effect of fattening period on the fattening ability and carcass of male Awassi lambs. Tar Bil Derg, 13: 372-378.

Tekin ME. 1991. The comparision of Turkish Merino and Lincoln $\mathrm{x}$ Turkish Merino $\left(\mathrm{F}_{1}\right)$ lambs in growth, fattening and carcass characteristics. Degree Diss, Ankara University, Ankara, Turkey.

Teklebrhan T, Urge M, Mekasha Y. 2012. Carcass measurement, conformation and composition of indigenous and crossbred (Dorper $x$ Indigenous) $F_{1}$ Sheep. Pak J Nutr, 11: $1055-1060$.
TSI 1987. Turkish Standards Institute TS 52737 Butchery Animals-Rules for Slaughtering and Carcass Preparation, Ankara, Turkey.

Tufan M, Akmaz A. 2001. Slaughter and carcass traits of Güney Karaman, Kangal Akkaraman and Akkaraman lambs at different slaughter weights. Turk J Vet Anim Sci, 25: 495504.

Ünal N, Atasoy F, Akçapınar H, Erdoğan M. 2003. Some production traits of Karayaka and Bafra (Chios x Karayaka $B_{1}$ ) sheep. Turk J Vet Anim Sci, 27: 265-272, 2003

Vacca GM, Carcangiu V, Dettori ML, Pazzola M, Mura MC, Luridiana S, Tilloca G. 2008. Productive performance and meat quality of Mouflon x Sarda and Sarda x Sarda suckling lambs. Meat Sci, 80: 326-334.

Yakan A, Ünal N. 2010. Meat production traits of a new sheep breed called Bafra in Turkey I. fattening, slaughter, and carcass characteristics of lambs. Trop Anim Health Prod, 42: 751-75. 